c. Die operasionele vlak van oorlogvoering. " $n$ Kort oorsig hieroor in die tydperk 1800 tot 1918 word verskaf.

d. Operasionele konsepte wat stagnasie in oorlogvoering, soos gedurende die Eerste Wêreldoor$\log , 1914-1918$, probeer verhoed. Hier gee Bellamy spesifiek aandag aan die sogenaamde Lugland geveg, die sogenaamde Operasionele Maneuvreringsgroep (OMG) soos ontwikkel in die Russiese en Sowjetleërs vanaf 1877-1945, die OMG in Asië, 1155-1418 en guerrilla-oorlogvoering in Asië, 1418-1975. Hierdie tydperke is met spesifieke verwysing na logistiek en state se ekonomiese vermoëns om militêre organisasies in stand te hou, bespreek. Verder is die werking van die operasionele vlak van oorlogvoering tydens hierdie veldtogte prakties geïllustreer, asook die rol van bevel, beheer, kommunikasie en inligting.

Bellamy gebruik sy bespreking om aan te toon dat die bestudering van krygsgeskiedenis verdedigingsbeplanners se taak vergemaklik.

Die skrywer gebruik ' $n$ interessante invalshoek om na sekere fasette van die evolusie van moderne landoorlogvoering te kyk. Om werklik reg te laat geskied aan so 'n omvattende onderwerp, verg egter meer as om net op Russiese en Oosterse oorlogvoering te fokus. Hy het ook nie werklik reg laat geskied aan die rol van bevel, beheer, kommunikasie en inligting in hierdie veldtogte nie. Dit word net terloops genoem. Weliswaar het hy hom ten doel gestel om ' $n$ inleidende studie oor die onderwerp te verskaf. Nogtans is te veel gefokus op sekere fasette van moderne landoorlogvoering wat die indruk kan skep dat dit al belangrike ontwikkeling was. In die proses word sekere fasette oorbeklemtoon terwyl belangrike ontwikkelinge in die evolusie van oorlogvoering onderskat word. In die bespreking van die Israeli's se operasie oor die Suez-kanaal in 1973 het hy 'n sterk argument gevoer om aan te toon dat die OMG werk en ' $n$ belangrike kenmerk van moderne landoorlogvoering is. Wat hy egter nalaat om te meld, is dat die OMG uit 'n gebalanseerde mag moet bestaan. Mobiele veggroepe beteken byvoorbeeld niks as daar nie ' $n$ sterk genoeg infanteriekomponent teenwoordig is om die pantser en artillerie te ondersteun nie. Hy kon ook in meer detail aangetoon het hoe ' $n$ gebrek aan behoorlike $C 3$ I ' $n$ OMG se operasie kan verongeluk.

Dit is ook te betwyfel of die onderwerpe wat hy gekies het voldoende antwoorde aan NAVO in 'n oorlog in Europa sou verskaf het. Nie almal sal saamstem dat ' $n$ Eurosentriese benadering nie hierin kan help nie. In Brittanje is in 1986 ' $n$ boek gepubliseer met die titel Old Battles and New Defences; Can we learn from Military History? Bekende Britse krygshistorici het hieraan meegewerk en hierdie boek verskaf net soveel bruikbare informasie oor ' $n$ moontlike oorlog in Europa teen die Warskouverdragslande soos dié van Bellamy.

Bellamy se boek het wel waarde in die sin dat dit die leser se aandag vestig op sekere belangrike ontwikkelinge in die evolusie van moderne landoorlogvoering. Die titel van die boek skep egter die indruk dat die boek al die belangrike fasette van die onderwerp aanspreek, wat beslis nie die geval is nie. Indien die subtitel eerder aangedui het dat belangrike lesse van konflikte waarin Russe en Oosterlinge betrokke was die kern van die bespreking vorm, sou dit minder gehinder het. Die keuse om oorlogvoering in Asië sover terug as Ghengis Khan te bespreek, is ook teenstrydig met die titel. In wese sukkel die skrywer om sintese te bereik deurdat daar te veel, te wyd bespreek word.

Ten spyte van bogenoemde kritiek lewer die boek tog ' $n$ belangrike bedrae tot beter begrip vir die aard van moderne landoorlogvoering. Die feit dat dit belangrike aspekte slegs terloops noem, bring egter mee dat die boek, soos wat die skrywer se doel was, slegs as inleidende studie oor die onderwerp gebruik kan word.

Lt kol C.J. Jacobs, Direktoraat Dokumentasiediens SANW, Privaatsak X289, Pretoria, 0001.

\section{DIE KAAPSE STAANDE MAG, 1872-1882}

\author{
J.S. Kotze \\ Staatsdrukker, Pretoria : 1993 \\ Opgeneem in die Argiefjaarboek vir \\ Suid-Afrikaanse Geskiedenis, jaargang 56. \\ 301 bladsye \\ ISBN 0797024867 \\ R20-00
}

Hierdie resensent is dankbaar dat hy oor iedere eksemplaar in die AJB reeks sedert 1938/1 beskik. Elke uitgawe, soms een soms twee per jaar, is ' $n$ winskoop wat prys, verskeidenheid en gehalte betref. Dit kan ook nie bra anders nie, want die bydraes in die tradisionele groen band is goedgekeurde Mverhandelinge en D-proefskrifte. Daarna is die inhoud weer eens nagegaan en kommentaar verwerk soos dit deur beoordelaars aangestip is toe opname in die AJB oorweeg is. In die lig van die lot van ander geslaagde reekse deur staatsbetrokkenheid, dink aan die Anglo-Boereoorlog en die Biografiese Woordeboek, kan ' $n$ mens maar net vertrou dat hierdie waardevolle reeks nie ook onthoof sal word nie.

Kotze se onderwerp, wat ' $n$ proefskrif vir die doktors- 
graad in Geskiedenis onder promotor D.J. van Zyl van die US in 1987 was, bevat benutbare kaarte, 'n verklaring rondom die afkortingslys, ' $n$ goed ingedeelde inhoudsopgawe, 'n nuttige Voorwoord, 'n oorwoë Slotsom (pp. 265-274), 'n Abstract en dan ' $n$ hoogs volledige verskeidenheidsvolle Bronnelys, plus die altyd nuttige Register. Tegnies dus, sluit die publikasie alles in wat nodig is. Ook die titel is kort en op die man af - die vlag dek inderdaad die lading!

Die nege hoofstukke met hulle subindelings val logies uiteen. Die aanloop van 1855-1872 is inleidend noodsaaklik. Die veel feite is nie ontmoedigend nie, want die tema móét op die voet af, van dag tot dag, van plek tot plek en van militêre eenheid tot militêre eenheid gevolg word. Mooi speur- en ontledingswerk is sodoende gelewer.

Wat opval, is die eindelose baie verwysings en toeligtings in voetnote. Argiefmateriaal is in oorvloed benut, maar met ' $n$ verskeidenheid ander leesmateriaal aangevul. Die taal/styl is heel leesbaar en aangenaam; iets wat altyd belangrik is, maar veral in ' $n$ byna verslag-tema soos hierdie onderwerp. Maar nogtans is die gebeure ook vertolk, deur die onderliggende regeringswoelinge en daardeur die militêre onsekerheid deel van die algemene geheel maak. Immers, ' $n$ hoë politieke prys is deur bv Molteno en deur Sprigg betaal omdat hulle verdedigingskemas misluk het.

'n Pragtige komponent is die inligting rakende die onderlinge verhouding tussen swart stamme, swart leiers en etniese eenhede wat wedersyds geraak word ook deur eie oorlog, eie grond en eie mag binne ' $n$ raamwerk van die Brits-Kaapse politiek. Ons vergeet te maklik dat grondgebied juis ook tussen swartes onderling ' $n$ strydpunt was en gebly het.

Uit ' $n$ militêre hoek bekyk, en, alle fasette van oorlog geniet die aandag van skrywer Kotze, is die publikasie van groot belang. Dit gaan om sommer baie aspekte van militêre verdediging, veldtogte en gevegte, veiligheid, militêre hervormings, herontplooiings, aanpassings, oorlog versus geldsteun, rebellie-opstande, belegpogings, logistieke stelsels, voorsorg- en opvolg operasies, eenhede wat omgeskep en saamgevoeg word asook die uitwerking van Kaapse bewindsveranderinge. Nee, dwarsdeur die uitgawe geniet hierdie kwessies aandag - iets wat die boek sekerlik 'n soort voorgeskrewe werk vir bepaalde militêre eenhede behoort te maak. ' $n$ Korps van bloot polisiëring en beveiliging het algaande ' $n$ militêre staande mag geword!

Suid-Afrika se uiteenlopende klimaat, landskappe en volkere het aan hom ' $n$ militêre vernuftigheid help besorg wat hy dalk in ' $n$ mindere mate oor sou beskik het as die patroon meer enkelvoudig was.
Hierdie waarheid word afgerond in Kotze se boek weergegee sonder dat hy dit as onderafdeling berekend toelig. Swart taktieke en Boer-Brit oorlogkombinasies het bepaald ' $n$ later gemeenskaplike, breër militêre uitgangspunt moontlik gemaak. Die Voorwoord plus hoofstuk 1 en 9 verwys geslaagd daarna.

Die publikasie is goed geproeflees. Terloops, op p. 134 lees 'n mens van "aanmars". Dit klink na "march on", maar kan seker ook met aanstap, aanloop verbind word. Verder, dit is jammer dat die geskrif nie ' $n$ enkele foto bevat nie. Uniforms, wapens, leiers of ' $n$ terrein sou sodoende beter bekend kon raak.

Gelukkig is ' $n$ volledige lys werke, wat in die Argiefjaarboek reeks opgeneem is, tussen pp. 293-301 ingesluit, want daardie inligting kan nie wyd genoeg bekend gestel word nie.

Prof Marius Swart, Departement Geskiedenis, Universiteit van Port Elizabeth.

\section{NAMIBIA'S LIBERATION STRUG- GLE; THE TWO-EDGED SWORD}

\author{
C. Leys and J.S. Saul \\ James Curry, London : 1995 \\ 212 bladsye \\ ISBN 085255 374-9
}

Die boek is die eindproduk van ' $n$ navorsingsprojek wat in die loop van 1989, die jaar van Namibië se onafhanklikheidswording, gestalte gekry het. Die navorsingsprojek het gepoog om die herinneringe aan ' $n$ 23-jarige bevrydingstryd wetenskaplik na te vors en vir die nageslag in geskrewe vorm te bewaar. Daar is gevolglik hoofsaaklik op die wording en aktiwiteite van die South West Africa People's Organization (SWAPO), plaaslik en in ballingskap, gekonsentreer. Die medewerkers beklee op een na almal akademiese poste. Benewens een historikus, Philip Steenkamp, is die politieke en sosiale wetenskappe, sterk verteenwoordig. Susan Brown, 'n voormalige joernalis, is tans ' $n$ ontwikkelingskonsultant in Namibië en die enigste nie-doserende medewerker.

Die title, Namibia's liberation struggle, suggereer dat hierdie boek net nog ' $n$ werk is oor die stryd om Namibië van koloniale oorheersing en die juk van apartheid te bevry. Die subtitel, The two edged sword, sê egter meer. Die twee-snydende swaard verwys ook na ' $n$ stryd binne SWAPO - ' $n$ stryd om die beweging van foute van die verlede en belemmerende faktore te bevry. In watter mate die beweging in sy eerste regeringsjare daarin geslaag het al dan nie, word inderdaad in hierdie boek aange- 